\title{
Approach of pulmonologists in Turkey to noninvasive mechanical ventilation use in acute respiratory failure
}

\begin{tabular}{|c|c|}
\hline 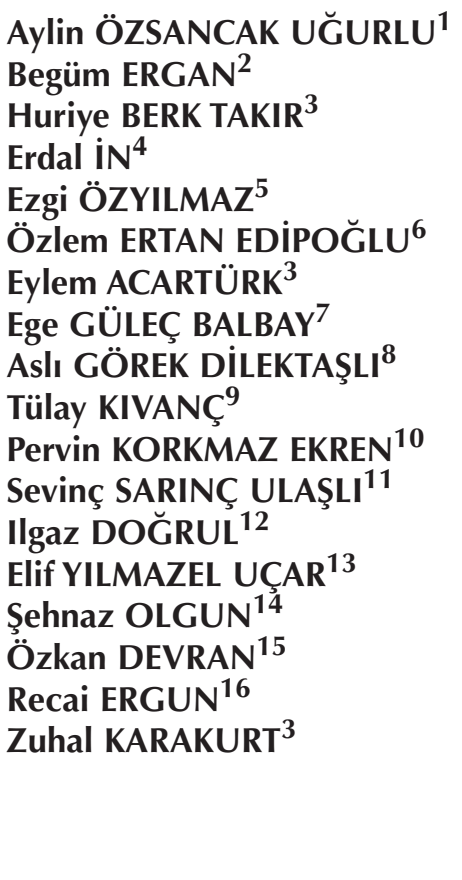 & $\begin{array}{l}1 \text { Department of Chest Diseases, Faculty of Medicine, Baskent University, Istanbul } \\
\text { Practice and Research Center, Istanbul, Turkey } \\
2 \text { Department of Chest Diseases, Faculty of Medicine, Dokuz Eylul University, Izmir, Turkey } \\
3 \text { Clinic of Chest Diseases, Sureyyapasa Chest Diseases and Chest Surgery Training and } \\
\text { Research Hospital, Istanbul, Turkey } \\
4 \text { Department of Chest Diseases, Faculty of Medicine, Firat University, Elazig, Turkey } \\
5 \text { Department of Chest Diseases, Faculty of Medicine, Cukurova University, Adana, Turkey } \\
6 \text { Clinic of Chest Diseases, Dr. Suat Seren Chest Diseases and Chest Surgery Training and } \\
\text { Research Hospital, Izmir, Turkey } \\
7 \text { Department of Chest Diseases, Faculty of Medicine, Duzce University, Duzce, Turkey } \\
8 \text { Department of Chest Diseases, Faculty of Medicine, Uludag University, Bursa, Turkey } \\
9 \text { Department of Chest Diseases, Faculty of Medicine, Baskent University, } \\
\text { Konya Practice and Research Hospital, Konya, Turkey } \\
{ }^{10} \text { Department of Chest Diseases, Faculty of Medicine, Ege University, Izmir, Turkey } \\
{ }^{11} \text { Department of Chest Diseases, Faculty of Medicine, Afyon Kocatepe University, } \\
\text { Afyon, Turkey } \\
{ }^{12} \text { Department of Chest Diseases, Faculty of Medicine, Baskent University, Ankara, Turkey } \\
{ }^{13} \text { Department of Chest Diseases, Faculty of Medicine, Ataturk University, } \\
\text { Suleyman Demirel Medical Center, Yakutiye Research Hospital, Erzurum, Turkey } \\
{ }^{14} \text { Department of Chest Diseases, Faculty of Medicine, Marmara University, Istanbul, Turkey } \\
{ }^{15} \text { Clinic of Chest Diseases, Ahi Evren Chests and Cardiovascular Surgery Training and } \\
\text { Research Hospital, Trabzon, Turkey } \\
{ }^{16} \text { Department of Chest Diseases, Faculty of Medicine, Yildirim Beyazit University, } \\
\text { Diskapi Training and Research Hospital, Ankara, Turkey }\end{array}$ \\
\hline
\end{tabular}

This study was presented as oral presentation at Turkish Thoracic Society $17^{\text {th }}$ Annual Congress and was honored by "Ümit Vaat Eden Çalışma" (Expectation promising study) award.

\section{SUMMARY}

Approach of pulmonologists in turkey to noninvasive mechanical ventilation use in acute respiratory failure

Introduction: Noninvasive mechanical ventilation (NIV) has been increasingly used worldwide for acute respiratory failure (ARF), especially in patients with chronic lung disorders. We aimed to define the approach of pulmonologists in Turkey to NIV use for ARF management.

\section{Yazışma Adresi (Address for Correspondence)}

Dr. Aylin ÖZSANCAK UĞURLU

Başkent Üniversitesi Tıp Fakültesi, İstanbul Uygulama ve Araştırma Merkezi, Gögüs Hastalıkları Anabilim Dalı, İstanbul-TURKEY

e-mail: aozsancak@hotmail.com 
Materials and Methods: A 38-question survey, developed and tested by authors, was distributed by e-mail to a total of 2.205 pulmonologists in Turkey.

Results: Response rate was $27 \%(n=596)$. Seventy-one percent of responders were practicing NIV in clinic. NIV use was found to be associated with responder's academic title, age, duration of medical license, type of physician's hospital and its region, patient load, NIV experience during residency, and duration of NIV and intensive care unit (ICU) experience ( $p<0.001)$. Based on sub-group analysis of responders using NIV, median number of NIV patients followed-up per week was 4 [interquartile range (IQR): 2-6]. Most of the NIV users reported employment of wards (90\%) and/or ICUs (86\%) to follow-up patients, while $8.4 \%$ of the responders were applying NIV only in ICU's. Chronic obstructive lung disease (COPD) (99.5\%), obesity hypoventilation syndrome (93.7\%) and restrictive lung disease (89.4\%) were the most common indications. Majority of NIV users (87\%) were applying NIV to > $60 \%$ of patients with COPD, and success rate in COPD was reported as over $60 \%$ by $93 \%$ of users. Oronasal mask (median and IQR 90 , 80-100\%, respectively) and home care NIV ventilators (median and IQR 50, 10-85\%, respectively) were the most commonly utilized equipment.

Conclusion: NIV use in ARF varies based on hospital type, region and, especially, experience of the physician. Although consistent with guidelines and general practice, NIV use can still be improved and increased.

Key words: Noninvasive ventilation, acute respiratory failure, survey, chronic obstructive pulmonary disease, intensive care unit, general wards

\section{ÖZET}

\section{Türkiye'de akut solunum yetmezliğinde noninvaziv mekanik ventilasyon kullanımına göğüs hastalıkları doktorlarının yaklaşımı}

Giriş: Noninvaziv mekanik ventilasyon (NIV) akut solunum yetmezliğinin (ASY) tedavisinde, özellikle de kronik akciğer hastalığı olan hastalarda, dünya çapında giderek artan oranlarda kullanılmaktadır. Bu çalışmada Türkiye'deki gögüüs hastalıkları doktorlarının ASY tedavisinde NIV kullanımına yönelik yaklaşımını belirlemeyi amaçladık.

Materyal ve Metod: Yazarlarca geliştirilen ve test edilen 38 soruluk anket, e-posta yoluyla Türkiye genelinde toplam 2205 göğüs hastalıkları doktoruna iletildi.

Bulgular: Katılım oranı \%27 ( $n=596)$ idi. Katılanların \%71'i klinikte NIV uygulaması yapıyordu. NIV kullanımı ile katılımcıların ünvanı, yaşı, doktorluk süresi, çalıştıkları hastane ve bulunduğu bölge, hasta yükü, asistanlık eğitimi esnasındaki NIV deneyimi ve miktarı, NIV ve yoğun bakım ünitesi (YBÜ) deneyim süreleri ilişkili bulundu (Tablo 1, p=0.000). ASY'de NIV kullanan 420 katılımcının alt grup analizinde, haftalık takip edilen ortanca hasta sayısı 4 (25 ve 75 persentil: 2.6) idi. Kullananların çoğunluğu servis (\% 90) ve/veya YBÜ (\%86)'de hastalarını takip ederken; \%8.4 hasta takibi için sadece YBÜ'yü kullanıyordu. En sık üç endikasyonu kronik obstrüktif akciğer hastalığı (\%99.5), obezite hipoventilasyon sendromu (\%93.7) ve restriktif akciğer hastalı̆̆ına (\%89.4) bağlı gelişen ASY idi. Kullanıcıların çoğunluğu (\%87) NIV'ı KOAH'ı hastaların \%60'ından fazlasında kullanmaktaydı ve kullananların \%93'ü KOAH'ılarda NIV başarı oranını \% 60'ın üzerinde olarak bildirmekteydi. Oronazal maske (ortanca, 25 ve 75 persentil: \% 90, 80, 100) ile ev tipi NIV ventilatörler (\%50, 10, 85) en sık kullanılan ekipmanlardı.

Sonuç: ASY'de NIV kullanımında bölgesel ve hastane kaynaklı, özellikle doktorun deneyimi ile ilişkili değişkenlik mevcuttur. Kılavuzlara ve genel pratiğe uygun olmakla birlikte, mevcut klinik NIV uygulamaları halen arttırılabilinir ve geliştirilebilinir.

Anahtar kelimeler: Noninvaziv ventilasyon, akut solunum yetmezliği, anket, kronik obstrüktif akciğer hastalı̆̆ı, yoğun bakım ünitesi, genel servis

\section{INTRODUCTION}

Noninvasive mechanical ventilation (NIV) has been recommended as a first-line treatment for acute respiratory failure (ARF) in patients with chronic obstructive pulmonary disease (COPD) during exacerbations or weaning/extubation, cardiogenic pulmonary edema (CPE) or immunosuppression (1-5). It has been increasingly used worldwide in ARF due to acute-on- chronic lung disorders (ACLD) and even non-COPD causes, with decreased mortality (6-9). Predictors of NIV success can be listed as the cause and type of ARF, the severity of the underlying disease, the experience and skills of the NIV-applying team, the equipment used or the location of the application $(10,11)$. Surveys done in Europe, America and India reflected the physicians and respiratory therapists' variable attitudes to NIV use (12-19).

NIV has also been used for ARF management in Turkey since the beginning of the 1990s, and case series and randomized controlled trials about the utilization of NIV have been published since then (20-25). These studies were mainly about the efficiency of NIV use in hypercapnic or hypoxic ARF at intensive care units (ICU) or intermediate care units 
(IMCU). There has been no epidemiologic data published about NIV use for ARF with different etiologies, treated not only in ICUs but also general wards or emergency departments (ED) in Turkey. In the present survey study, we aimed to define the approach of pulmonologists in Turkey to NIV use in ARF by using a questionnaire.

\section{MATERIALS and METHODS}

The questionnaire was developed by the authors (AOU and ZK) based on the review of previously published surveys about NIV, personal experiences and perceived areas of interest. Clarity and reliability of the questions were evaluated by pilot testing done by 10 physicians and all of the authors. Based on the feedback, the final version of the 38-question, selfadministered survey was formed. The study protocol was approved by the Ethics Committee at Baskent University Faculty of Medicine.

An e-mail asking for participation in the survey, with the questionnaire attached, was sent to the target population, 2.205 pulmonologists in Turkey, in November 2013. To improve the response rate, e-mail, telephone or face-to-face follow-ups were conducted for non-responders.

The questions were related to the profile of the participant (including NIV and ICU experience), characteristics of his/her current hospital (type and region) and current use of NIV in clinical practice. Hospitals were sub-grouped as teaching (including university, pulmonary/general research and training hospitals) and non-teaching (state, pulmonary branch and private hospitals). NIV users were further questioned about indications of NIV for ARF, location of NIV application and estimated NIV success rates, equipment used and related complications. The data about NIV use for chronic respiratory failure was evaluated in another study.

\section{Statistical Analysis}

Statistical analysis was performed using SPSS statistical analysis software, version 12.0 (SPSS Inc., Chicago, IL, USA). Since the distribution of most of the continuous variables was not normal, data was expressed as the median [interquartile range (IQR)] unless otherwise specified. The chi-square test was used for categorical data, whereas the Mann-Whitney $U$ test was used for continuous data when appropriate. Spearman's rank correlation coefficient was used to compare continuous variables, such as the rela- tionship between the age of the physician or duration of NIV experience and the estimated frequency of NIV use for causal diagnosis. A $p$ value of less than 0.05 was considered statistically significant.

\section{RESULTS}

\section{Response Rate NIV Utilization}

Survey responses were completed between November 2013 and February 2014, with a response rate of $27.1 \%(n=596)$. Participation was mainly from specialists $[(55.7 \%)$ vs. academicians $(24.2 \%)$ and residents $(20.1 \%))$, teaching hospitals $(64.6 \%)$ vs. nonteaching (35.4\%)] and the Marmara region (30.9\%).

Most of the responders ( $n=420,70.5 \%)$ reported use of NIV in their routine clinical practice. The factors found to be associated with NIV use are listed in Figure $1 \mathrm{~A}-\mathrm{C}$ and Table 1. The teaching status of the centers differed regionally (Table 2 ).

\section{Indications for NIV}

The median number of patients treated by NIV per week was reported as 4 (2-6) by the NIV users. The three most frequent indications for NIV use in ARF were exacerbation of COPD (99.5\%), decompensation of obesity hypoventilation syndrome (OHS) $(93.7 \%)$ and restrictive lung disease (RLD) (89.4\%) (Figure 2). Although there was no association between hospital profile (region and type) and NIV use in COPD, OHS, asthma or postoperative ARF, there was an association for the rest of the indications with hospital type and/or region $(p<0.05)$ (Table 3).

Among physicians using NIV, the estimated frequency of NIV use for specific conditions varied, with the majority of the physicians using NIV for greater than $60 \%$ of cases with COPD exacerbation (Table 4). The association between estimated frequency of NIV for relatively uncommon indications (CPE, pneumonia, post-extubation, weaning, ARDS) and age of the physician $(r=-0.120,-0.100,-0.132,-0.116$ and -0.210 and $p=0.017,0.047,0.009,0.022$ and 0.000 , respectively) was negative; however, the association was positive for those indications and the number of patients treated with NIV during residency $(r=0.125$, $0.145,0.145,0.117$ and 0.163 and $p=0.016,0.005$, $0.005,0.025$ and 0.002 , respectively). The association was also positive between more common indications (COPD, RLD, OHS) and the duration of NIV experience $(r=0.124,0.187$ and 0.127 , and $p=0.013$, 0.000 and 0.013 , respectively). 

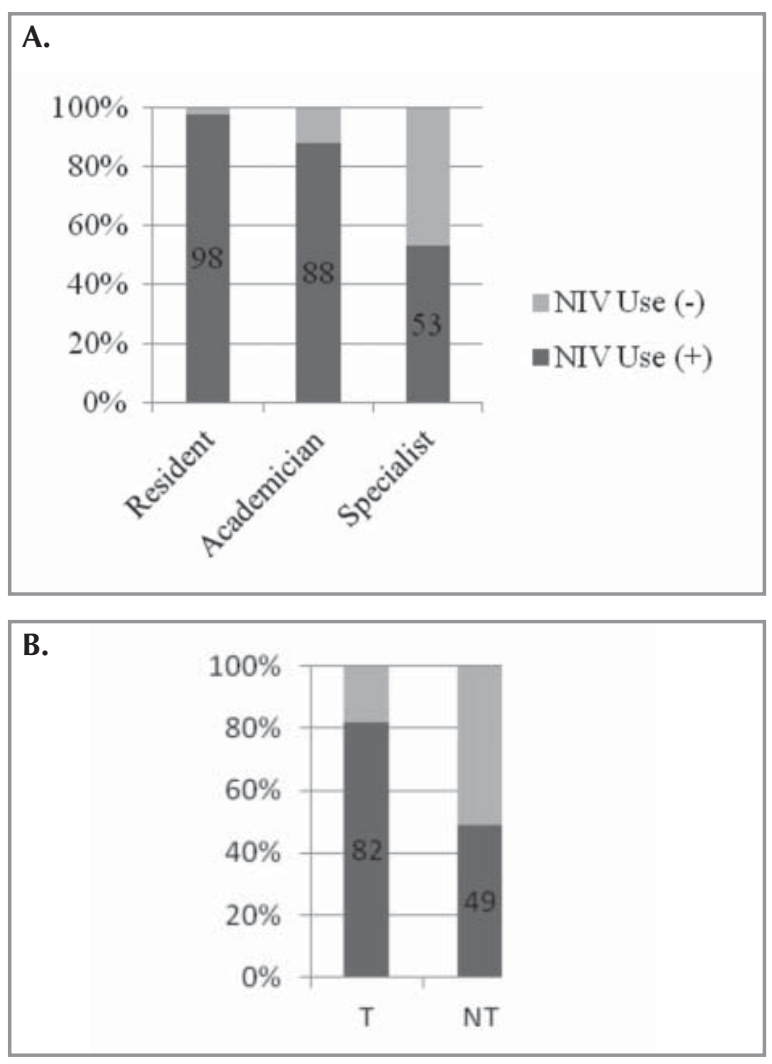

C.

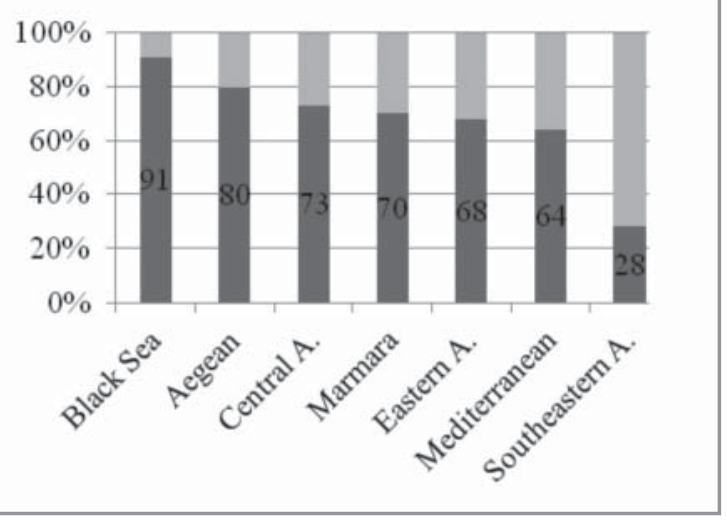

Figure 1. Use of noninvasive ventilation based on: (A) Title of the physician, (B) Type of the hospital, (C) Region of the hospital*.

A: Anatolia, NIV: Noninvasive ventilation, NT: Non-teaching, T: Teaching.

$* \mathrm{p}<0.001$ for all variables.

\section{Site of NIV Application}

The majority of the NIV users was applying it on general wards $(90.0 \%)$ or in ICUs $(86.0 \%)$, followed by IMCUs (67.4\%) and EDs (57.4\%). NIV use was
Table 1. The comparative characteristics of physicians using vs. not using NIV in practice*

\begin{tabular}{|c|c|c|}
\hline & $\begin{array}{l}\text { NIV users } \\
(n=420)\end{array}$ & $\begin{array}{c}\text { NIV nonusers } \\
(n=176)\end{array}$ \\
\hline Age, years & $36.5(31-42)$ & $42.0(35-48)$ \\
\hline $\begin{array}{l}\text { Duration of working in } \\
\text { pulmonary field, years }\end{array}$ & $10.0(4-16)$ & $14.0(9-20)$ \\
\hline Daily outpatient number & $30.0(20-50)$ & $40.0(30-50)$ \\
\hline $\begin{array}{l}\text { NIV experience during } \\
\text { training, } \mathrm{n}(\%)\end{array}$ & $314(75)$ & $87(49)$ \\
\hline $\begin{array}{l}\text { Number of patients treated } \\
\text { with NIV during training }\end{array}$ & $100.0(0-300)$ & $10.0(0-100)$ \\
\hline $\begin{array}{l}\text { Duration of NIV } \\
\text { experience, years }\end{array}$ & $6.0(3-10)$ & $3.5(0-7)$ \\
\hline ICU experience, n (\%) & $265(64)$ & $57(33)$ \\
\hline $\begin{array}{l}\text { Duration of ICU } \\
\text { experience, months }\end{array}$ & $3.0(0-24)$ & $0(0-3)$ \\
\hline \multicolumn{3}{|c|}{$\begin{array}{l}\text { NIV: Noninvasive mechanical ventilation, ICU: Intensive care unit. } \\
{ }^{*} p<0.001 \text { for all variables. } \\
\text { Categorical variables were shown as } \mathrm{n}(\%) \text {, whereas continuous } \\
\text { variables as median (interquartile range). }\end{array}$} \\
\hline
\end{tabular}

Table 2. Regional distribution of participating

pulmonologists using NIV based on teaching

status of their hospital*

\begin{tabular}{|lcc|}
\hline & Teaching & Non-teaching \\
\hline Aegean & $64(74.4)$ & $22(25.6)$ \\
Black sea & $26(66.7)$ & $13(33.3)$ \\
Central anatolia & $59(93.7)$ & $4(6.3)$ \\
Eastern anatolia & $26(63.4)$ & $15(36.6)$ \\
Marmara & $109(85.2)$ & $19(14.8)$ \\
Mediterranean & $20(40)$ & $30(60)$ \\
South-eastern anatolia & $13(100)$ & 0 \\
Total & $317(75.5)$ & $103(24.5)$ \\
\hline * Numbers were shown as $\mathrm{n}(\%$ within region), $\mathrm{p}<0.001$. \\
\hline
\end{tabular}

more common in all units in teaching than nonteaching hospitals, especially being more significant outside-of-ICU (70.7 vs. $17.5 \%$ in EDs, 96.2 vs. $70.9 \%$ on wards, 74.1 vs. $46.6 \%$ in IMCUs, respectively $(p<0.001)$ and 89.3 vs. $75.7 \%$ in ICUs, respectively $(p<0.005))$.

Only a small fraction of physicians $(8.4 \%)$, most of whom were specialists $(94.1 \%)$ and from non-teaching hospitals $(88.2 \%)(p<0.001)$, were using NIV only in ICU and/or IMCU. The main reasons for this were reported as a lack of trained staff $(90 \%)$, equipment $(74 \%)$ or training (55\%). Responders using NIV 
Özsancak Uğurlu A, Ergan B, Berk Takır H, İn E, Özyılmaz E, Ertan Edipoğlu Ö, Acartürk E, Güleç Balbay E, Görek Dilektaşlı A, Kıvanç T, Korkmaz Ekren P, Sarınç Ulaşlı S, Doğrul I, Yılmazel Uçar E, Olgun Ş, Devran Ö, Ergun R, Karakurt Z.

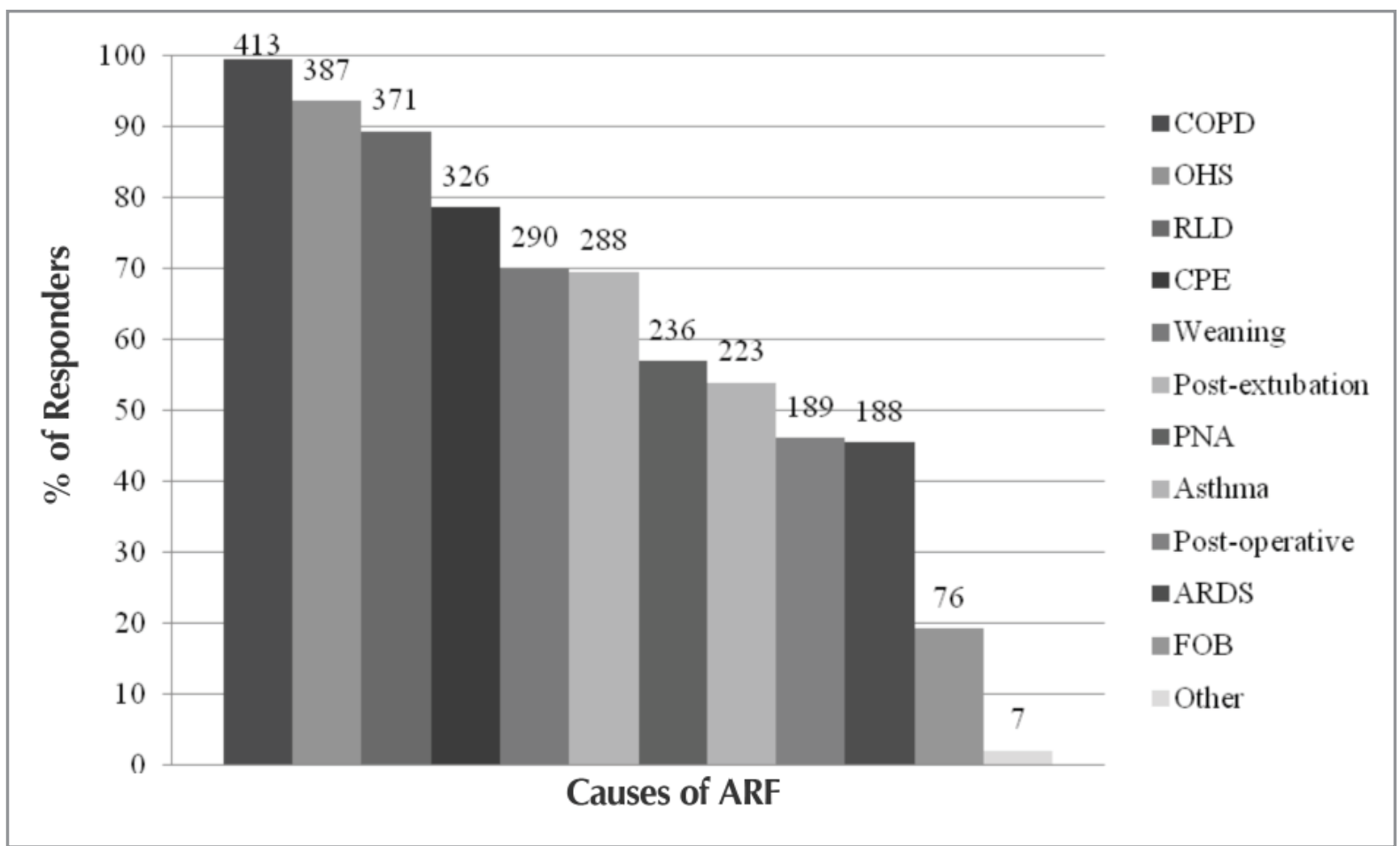

Figure 2. Causes of ARF treated with noninvasive ventilation ${ }^{1}$.

ARDS: Acute respiratory distress syndrome, COPD: Chronic obstructive pulmonary disease, CPE: Cardiogenic pulmonary edema, FOB: Fiberoptic bronchoscopy, OHS: Obesity hypoventilation syndrome, PNA: Pneumonia, RLD: Restrictive lung disease.

${ }^{1}$ Numbers given on the bars are the absolute numbers of physicians using NIV in that condition.

Table 3. Distribution of pulmonologist using NIV for different etiologies among (A) regions and (B) hospitals (teaching vs. non-teaching) ${ }^{(1-3)}$

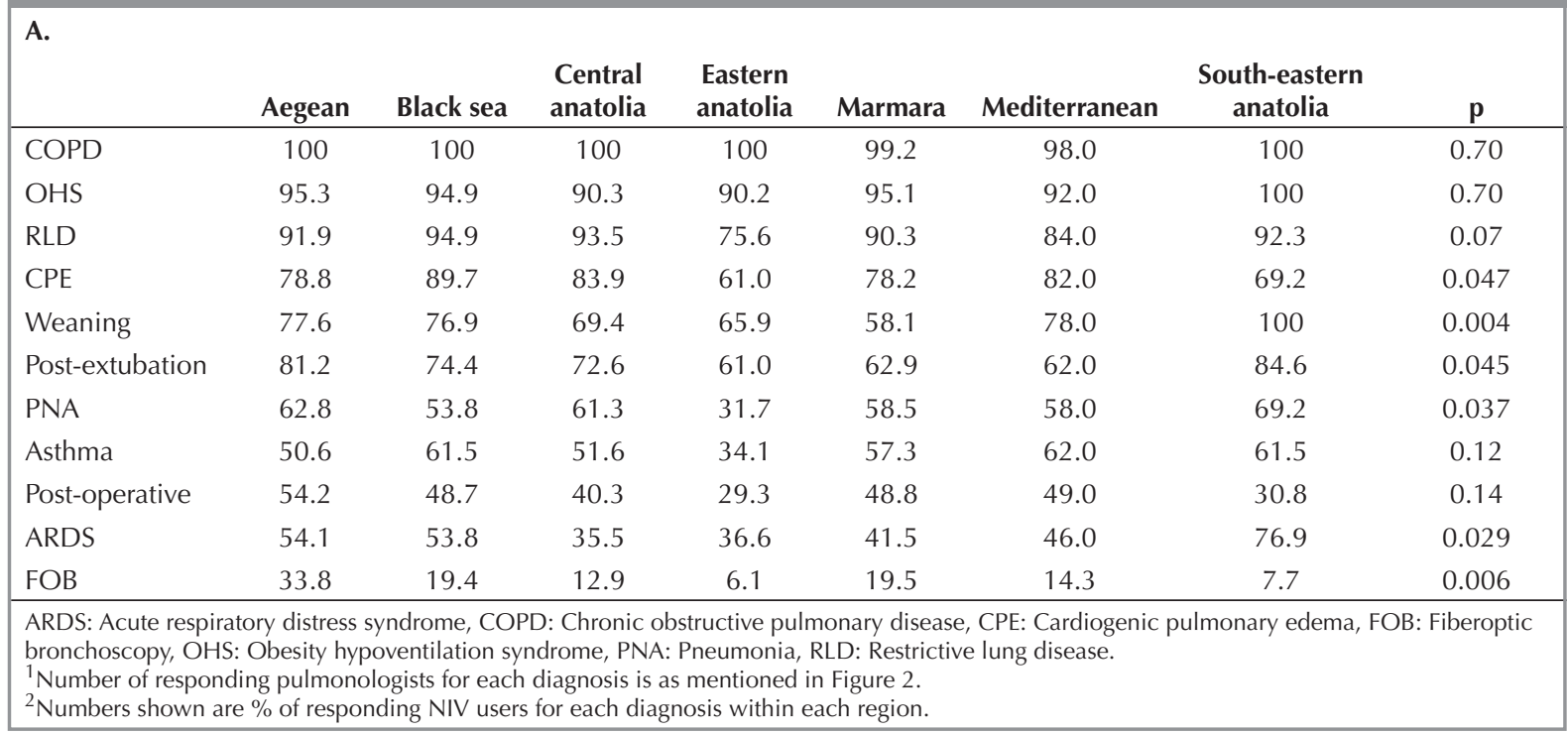


Table 3. Distribution of pulmonologist using NIV for

different etiologies among $(\mathbf{A})$ regions and $(\mathbf{B})$ hospitals (teaching vs. non-teaching) ${ }^{(1-3)}$ (devamı).

B.

\begin{tabular}{lccc} 
& Teaching & Non-teaching & p \\
\hline COPD & 99.4 & 100 & 0.42 \\
OHS & 94.5 & 91.2 & 0.23 \\
RLD & 91.7 & 82.5 & 0.009 \\
CPE & 81.7 & 69.6 & 0.009 \\
Weaning & 70.4 & 68.9 & 0.78 \\
Post-extubation & 73.4 & 57.8 & 0.003 \\
PNA & 61.1 & 44.7 & 0.004 \\
Asthma & 54.0 & 53.4 & 0.91 \\
Post-operative & 47.1 & 43.0 & 0.48 \\
ARDS & 45.5 & 45.6 & 0.33 \\
FOB & 22.1 & 10.3 & 0.011
\end{tabular}

ARDS: Acute respiratory distress syndrome, COPD: Chronic obstructive pulmonary disease, CPE: Cardiogenic pulmonary edema, FOB:

Fiberoptic bronchoscopy, OHS: Obesity hypoventilation syndrome,

PNA: Pneumonia, RLD: Restrictive lung disease.

outside-of-ICU listed a shortage of ICU beds (77\%), managing less severe cases of ARF in other units $(64 \%)$, increased experience $(63 \%)$ and evidence $(53 \%)$ for NIV use as main reasons for it.

Physicians using NIV for COPD exacerbations, RLD, $\mathrm{CPE}$ or decompensation of OHS reported mostly general wards as the site of application (Figure 3). On the contrary, most of the physicians stated an ICU as the only location of NIV use for weaning $(61.3 \%)$, ARDS $(55.9 \%)$, post-extubation (50.4\%)/post-operative (61.0\%) ARF and during application of FOB (31.8\%).

\section{Perceived NIV Success Rates}

Most of the responders estimated the success rate of NIV to be "high" for most of the causal diagnoses, except for pneumonia and ARDS (Figure 4). These rates were generally found to be higher in academicians or residents than specialists and in teaching hospitals than non-teaching ones (except for OHS, weaning, pneumonia, ARDS and post-operative ARF) $(p<0.05)$ (Table 5). The association between perceived NIV success rate for relatively uncommon indications (CPE, pneumonia, post-extubation, ARDS) and age of the physician $(r=-0.110,-0.147,-0.138$ and -0.146 and $p=0.038,0.005,0.009$ and 0.008, respectively) was negative, as was also shown for estimated frequency of indications.

\section{Equipment Used for NIV and Related Complications}

Oronasal mask and home care noninvasive ventilators were the most commonly preferred equipment for most of the cases (Table 6). The mask and ventilator type was found to be associated with the title of the physician, hospital type, cause of ARF or site of application $(\mathrm{p}<0.05)$ (Table 7).

Humidification during NIV was used by only $53 \%$ of the responders.

Intolerance of the mask (86.9\% of the responders), gastric distension (80\%) and skin lesions $(77.4 \%)$ were the most commonly reported NIV related complications. Other complications were listed as mouth

Table 4. Perceived frequency of NIV utilization for each causal diagnosis ${ }^{1}$

\begin{tabular}{|c|c|c|c|c|c|c|}
\hline & $\begin{array}{c}\text { Never } \\
(0 \%)\end{array}$ & $\begin{array}{c}\text { Rare } \\
(1-20 \%)\end{array}$ & $\begin{array}{c}\text { Few } \\
(21-40 \%)\end{array}$ & $\begin{array}{l}\text { Moderate } \\
(41-60 \%)\end{array}$ & $\begin{array}{l}\text { Often } \\
(61-80 \%)\end{array}$ & $\begin{array}{l}\text { Most often } \\
(81-100 \%)\end{array}$ \\
\hline COPD & 0.5 & 0.5 & 1.4 & 9.7 & 25.6 & 62.3 \\
\hline $\mathrm{OHS}$ & 6.0 & 8.0 & 5.0 & 14.1 & 29.2 & 37.7 \\
\hline RLD & 10.8 & 5.1 & 15.2 & 22.8 & 26.7 & 19.4 \\
\hline CPE & 21.9 & 5.0 & 15.2 & 24.6 & 20.6 & 12.7 \\
\hline Weaning & 30.7 & 5.8 & 5.1 & 16.2 & 23.9 & 18.3 \\
\hline Post-extubation & 31.5 & 8.5 & 4.3 & 13.2 & 24.5 & 18.0 \\
\hline PNA & 44.1 & 7.9 & 11.1 & 18.6 & 12.4 & 5.9 \\
\hline Asthma & 46.0 & 13.1 & 9.0 & 13.6 & 10.2 & 8.1 \\
\hline Post-operative & 55.7 & 9.1 & 10.8 & 10.8 & 9.6 & 4.0 \\
\hline ARDS & 55.8 & 7.4 & 6.5 & 11.7 & 10.2 & 8.4 \\
\hline FOB & 81.2 & 4.6 & 6.3 & 4.6 & 1.3 & 2.0 \\
\hline \multicolumn{7}{|c|}{$\begin{array}{l}\text { ARDS: Acute respiratory distress syndrome, COPD: Chronic obstructive pulmonary disease, CPE: Cardiogenic pulmonary edema, FOB: Fiberopti } \\
\text { bronchoscopy, OHS: Obesity hypoventilation syndrome, PNA: Pneumonia, RLD: Restrictive lung disease. } \\
{ }^{1} \text { Number of responders for } \mathrm{COPD}=414, \mathrm{OHS}=401, \mathrm{RLD}=408, \mathrm{CPE}=402, \text { Weaning }=394 \text {, Post-extubation }=400, \mathrm{PNA}=404, \mathrm{Asthma}=411 \text {, } \\
\text { Post-operative }=397, \mathrm{ARDS}=403, \mathrm{FOB}=394 .\end{array}$} \\
\hline
\end{tabular}




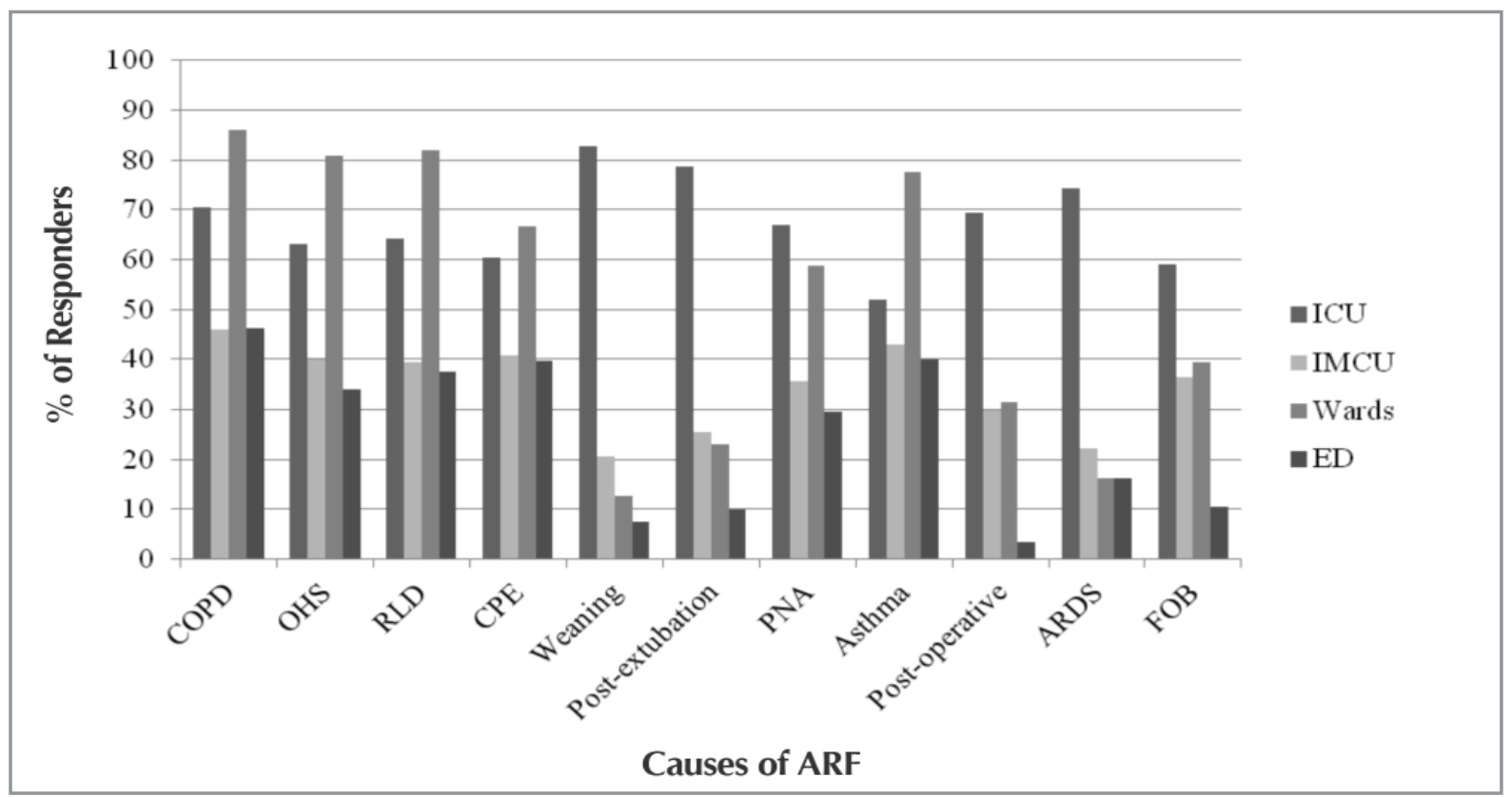

Figure 3. Preference of physicians for sites of noninvasive ventilation use ${ }^{1,2}$.

ARDS: Acute respiratory distress syndrome, COPD: Chronic obstructive pulmonary disease, CPE: Cardiogenic pulmonary edema, FOB: Fiberoptic bronchoscopy, OHS: Obesity hypoventilation syndrome, PNA: Pneumonia, RLD: Restrictive lung disease, ED: Emergency department, ICU: Intensive care unit, IMCU: Intermediate care unit.

${ }^{1}$ More than one site could be stated for each specific condition by a physician.

${ }^{2}$ Number of responders for $\mathrm{COPD}=408, \mathrm{OHS}=378, \mathrm{RLD}=358, \mathrm{CPE}=314$, Weaning $=277$, Post-extubation $=274, \mathrm{PNA}=224$, Asthma $=165$, Post-operative $=174, \mathrm{ARDS}=179, \mathrm{FOB}=66$.

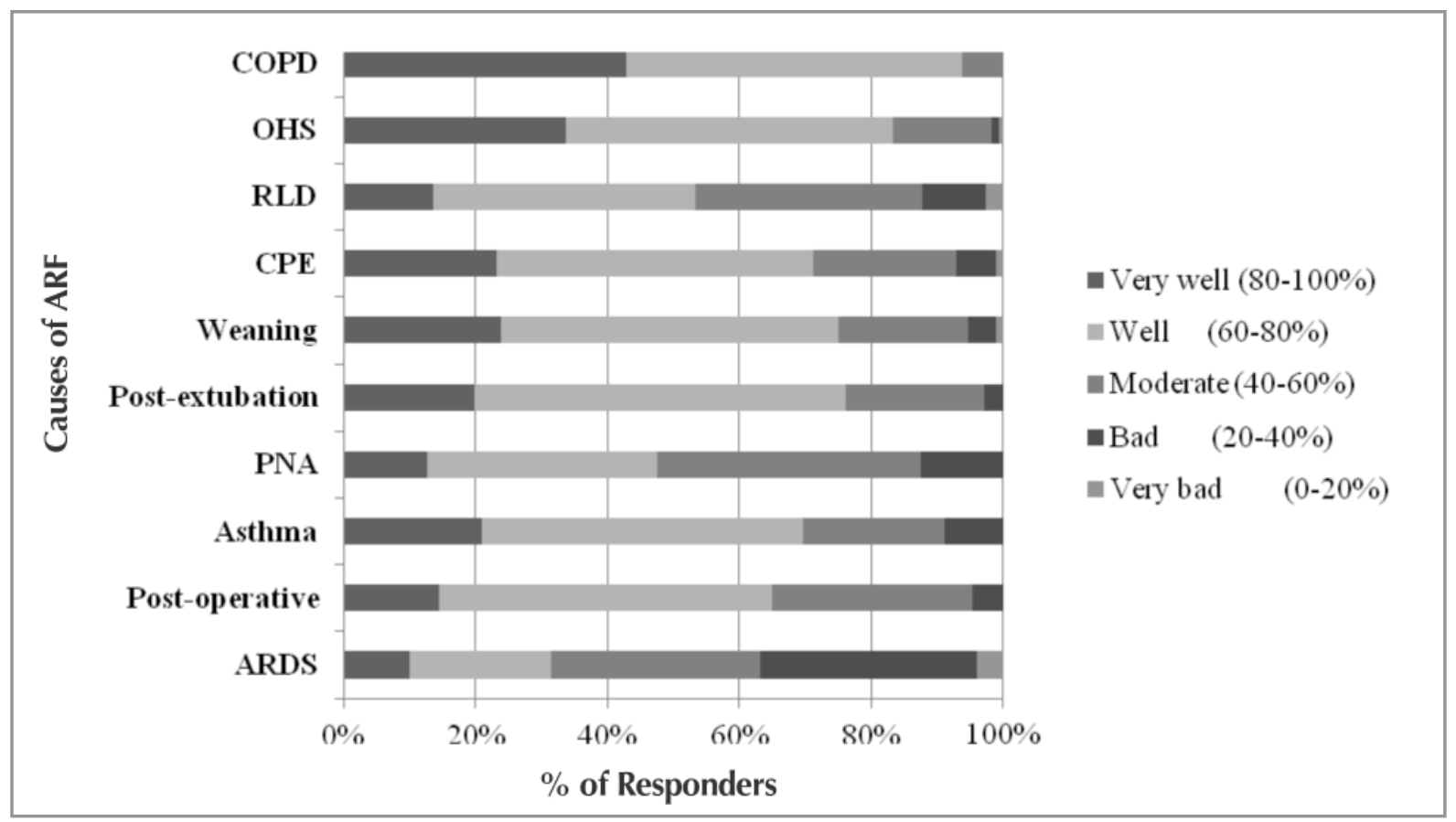

Figure 4. Estimated success rate of noninvasive ventilation for each causal diagnosis ${ }^{1}$.

ARDS: Acute respiratory distress syndrome, COPD: Chronic obstructive pulmonary disease, CPE: Cardiogenic pulmonary edema, OHS: Obesity hypoventilation syndrome, PNA: Pneumonia, RLD: Restrictive lung disease.

${ }^{1}$ Number of responders for $\mathrm{COPD}=394, \mathrm{OHS}=351, \mathrm{RLD}=341, \mathrm{CPE}=281$, Weaning $=239$, Post-extubation $=242, \mathrm{PNA}=198$, Asthma $=191$, Post-operative $=131$, ARDS $=149$. 


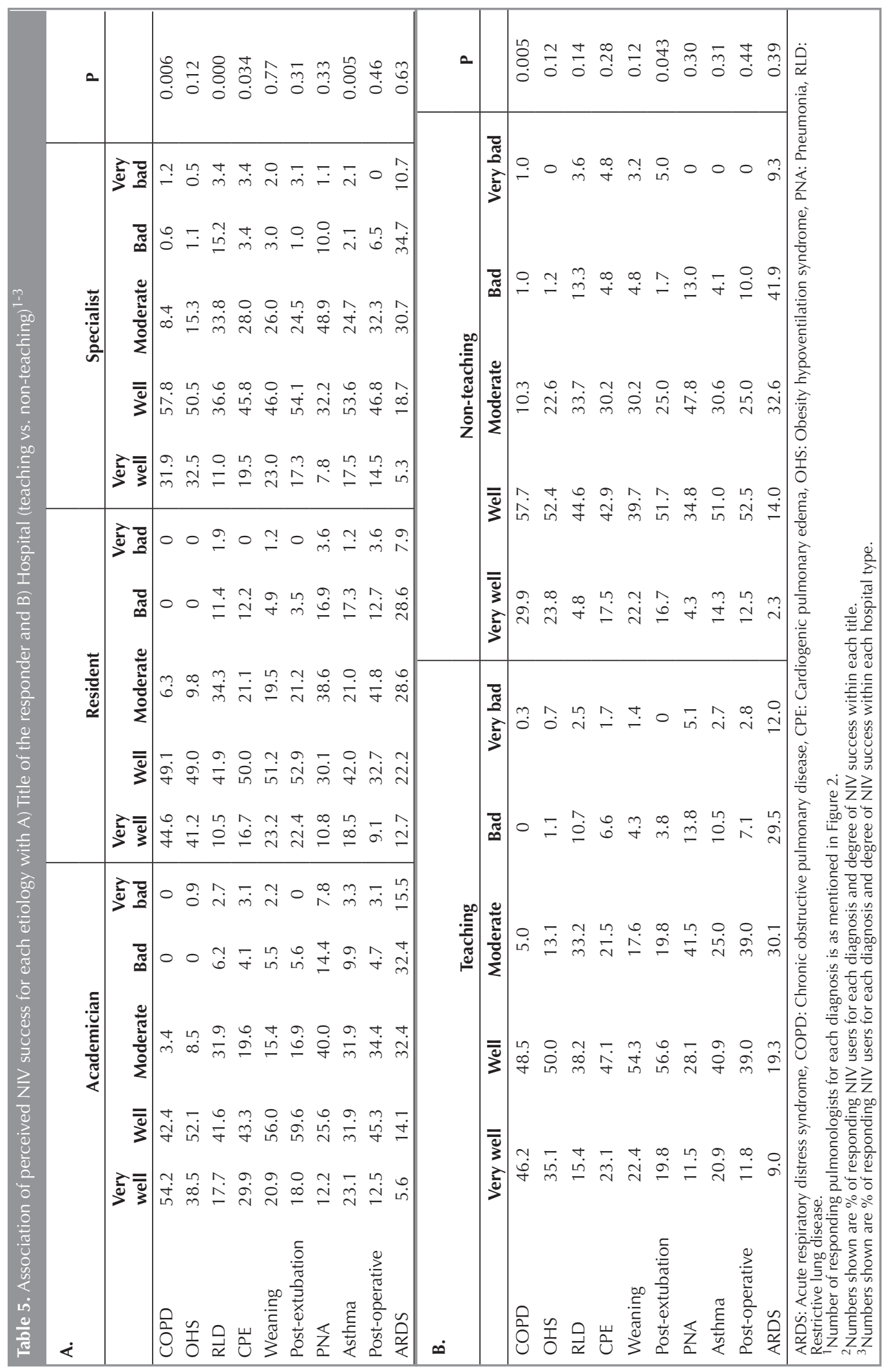


Özsancak Uğurlu A, Ergan B, Berk Takır H, İn E, Özyılmaz E, Ertan Edipoğlu Ö, Acartürk E, Güleç Balbay E, Görek Dilektaşlı A, Kıvanç T, Korkmaz Ekren P, Sarınç Ulaşlı S, Doğrul I, Yılmazel Uçar E, Olgun Ş, Devran Ö, Ergun R, Karakurt Z.

\begin{tabular}{|lcc|}
\hline Table 6. Equipments used for NIV management ${ }^{1}$ & & \\
\hline & $\mathbf{n}(\%)$ of responders & Estimated frequency of prescription (\%) \\
\hline Masks & & $90(80-100)$ \\
Oronasal mask & $402(95.7)$ & $5(0-15)$ \\
Nasal mask & $232(55.2)$ & $0(0-5)$ \\
Total face mask & $138(32.9)$ & $0(0-0)$ \\
Helmet & $40(9.5)$ & $50(10-85)$ \\
Ventilators & & $4(0-33.8)$ \\
Home care noninvasive ventilators & $311(74.0)$ & $10(0-50)$ \\
Hospital type specific noninvasive ventilators & $195(46.4)$ & $0(0-0)$ \\
ICU ventilators with NIV module & $255(60.7)$ & $75(17.9)$ \\
ICU ventilators without a NIV module & \\
\hline More than one type of mask/ventilator could be stated by a physician. & \\
Categorical variables were shown as $\mathrm{n}(\%)$, whereas continuous variables as median (interquartile range). & \\
\hline
\end{tabular}

dryness $(73 \%)$, nasal congestion $(53.5 \%)$, claustrophobia (44\%), epistaxis (31.9\%), allergic reactions $(26 \%)$, sinus pressure $(11.6 \%)$ and others $(1.6 \%)$.

\section{DISCUSSION}

In this first national survey, we demonstrated that:

1) There is great variability in NIV use for ARF, depending mainly on experience and knowledge of the physician, but NIV use is also related to the type and the region of the hospital;

2) NIV use is more common and is perceived to be more successful in acute-on-chronic lung disorders (ACLD); and

3) The site of NIV application is not limited to the ICU for the majority of the physicians, and its limitation is mainly due to inadequacy of equipment, training or trained staff.

In our survey, the proportion of the pulmonologists using NIV in ARF was nearly 70\%. The pulmonologists not using NIV in practice were older specialists, generally from non-teaching hospitals of different regions of Turkey, with a higher patient load and longer experience in the pulmonary field but lower experience in NIV use and ICU. The rate and the associations were reported similarly in Ontario and India surveys $(16,18)$. However, it is important to underline that half of our NIV non-users had NIV training during fellowship, with a median of 3.5 years of experience, and some of them cited a lack of adequate equipment, trained medical staff and appropriate facilities for follow-up of NIV patients rather than poor previous experience in NIV use (oral communication). Therefore, these rates might still be increased with post-training educational courses and new medical policies (including an increase in equipment and medical staff).

Utilization of NIV has been increasing worldwide, probably due to increased evidence and experience, as well as published guidelines favoring increased NIV use, especially for diagnoses like COPD and CPE (5-9,26-29). COPD was shown to be the most frequent indication in most of the previous surveys, and NIV utilization rate for ACLD is shown to be mid-70s in real-life studies $(7,8,12,16-19)$. Our findings were consistent with these, as ACLD were the most common indications for NIV use. Nearly 90\% of responders were using NIV for exacerbation of COPD for more than $60 \%$ of the cases. OHS, which for NIV was shown to be equally effective with better outcomes than COPD by Carrillo et al., was the second most common indication after COPD (30). We found the rate of physicians using NIV for CPE to be similar or quite lower than rates in prior surveys, which could be due to the application of NIV by cardiologists without consulting pulmonologists in their units (14,16-18). Probably based on the growing evidence on the use of NIV during weaning or for post-extubation ARF, more than $60 \%$ of our responders noted quite frequent NIV use in these conditions (28). It is still controversial to use NIV in patients with de novo ARF (including pneumonia and ARDS), whereas application of NIV during FOB is recommended to be reserved for experienced centers; our lower rates of NIV use in these conditions were consistent with these suggestions (4). 


\begin{tabular}{|c|c|c|c|c|c|c|}
\hline 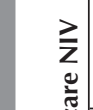 & $=$ & ôे & ڤે & 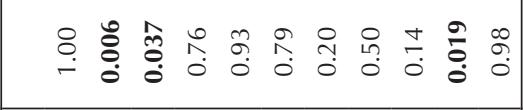 & 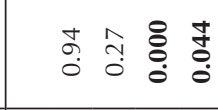 & 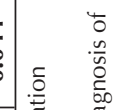 \\
\hline 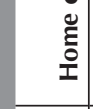 & & 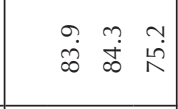 & 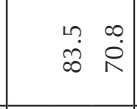 & 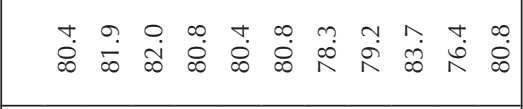 & 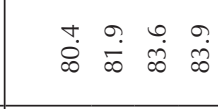 & 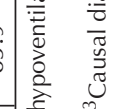 \\
\hline 茫 & $=$ & $\ddot{m}$ & ֻे & 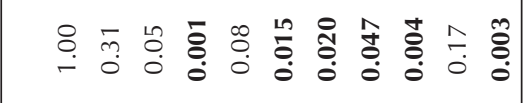 & 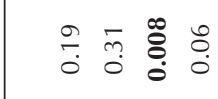 & 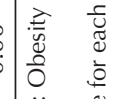 \\
\hline : & & 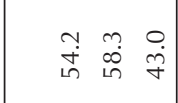 & 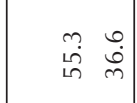 & 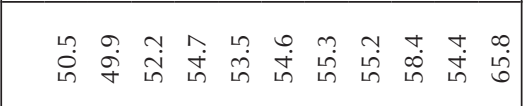 & 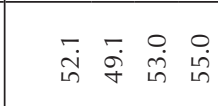 & 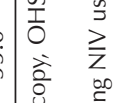 \\
\hline 竞离 & $=$ & $\stackrel{0}{0}$ & $\stackrel{\bar{m}}{\stackrel{0}{0}}$ & 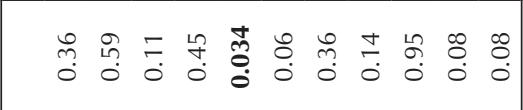 & 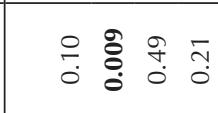 & 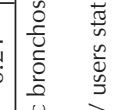 \\
\hline 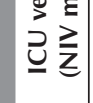 & & $\underset{i}{i} \stackrel{m}{\grave{i}} \stackrel{\grave{i}}{i}$ & 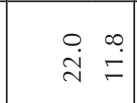 & 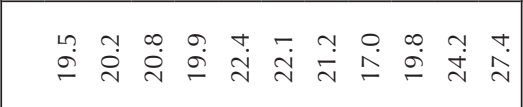 & 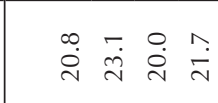 & 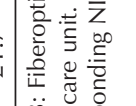 \\
\hline 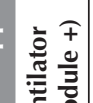 & $=$ & Ji & $\stackrel{n}{\circ}$ & 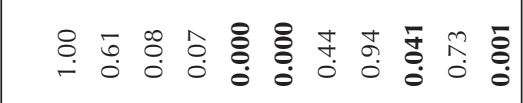 & 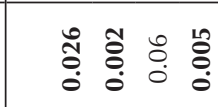 & 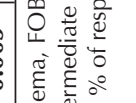 \\
\hline 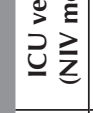 & & $\begin{array}{lll}\stackrel{i}{i} & \ddot{b} & \hat{\sigma}\end{array}$ & $\begin{array}{ll}\sigma & ? \\
\hat{B} & \stackrel{\Gamma}{\Gamma}\end{array}$ & 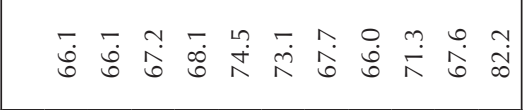 & 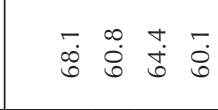 & 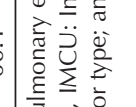 \\
\hline $\bar{\Xi}$ & $=$ & $\stackrel{\leftrightarrow}{\circ}$ & 宅 & 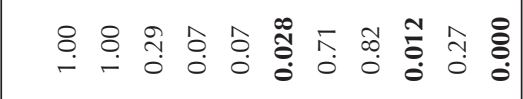 & 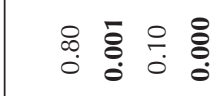 & 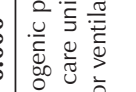 \\
\hline$\overline{\bar{I}}$ & & 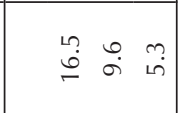 & $\hat{i}$ & 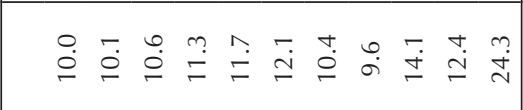 & 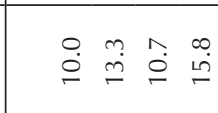 & 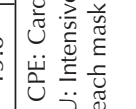 \\
\hline$\Sigma$ & $=$ & $\stackrel{\infty}{\infty}$ & $\underset{0}{0}$ & 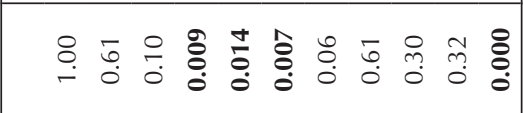 & $\begin{array}{llll}n & n & \infty & n \\
\infty & m & 0 \\
0 & 0 & 0 & 0 \\
0 & 0 & 0 \\
0\end{array}$ & 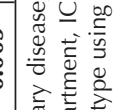 \\
\hline$F$ & & 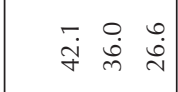 & $\begin{array}{ll}\stackrel{0}{0} & \stackrel{1}{0} \\
\dot{m} & \stackrel{\leftrightarrow}{\sim}\end{array}$ & 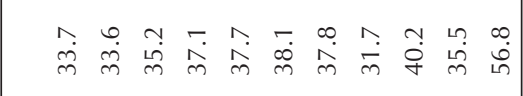 & 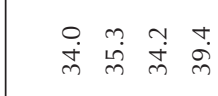 & 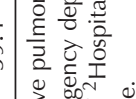 \\
\hline$\sum$ & $=$ & กี & $\underset{0}{0}$ & 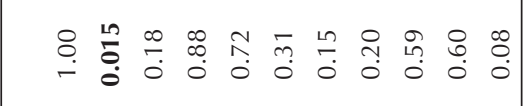 & 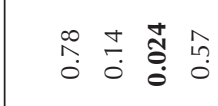 & 胥 \\
\hline & & 엉 & 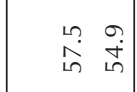 & 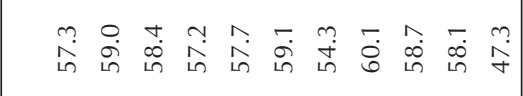 & 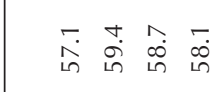 & $\underset{0}{0}$ \\
\hline$\Sigma$ & $=$ & $\underset{\sim}{\stackrel{\circ}{\circ}}$ & $\begin{array}{l}12 \\
0 \\
0 \\
0\end{array}$ & 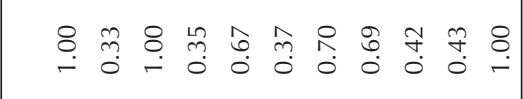 & 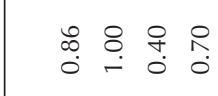 & 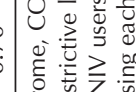 \\
\hline o & & $\begin{array}{ccc}m & m \\
\infty & \sigma & \sigma \\
\sigma & \infty\end{array}$ & $\begin{array}{cc}1 & 0 \\
\infty & \infty \\
\infty & \infty\end{array}$ & 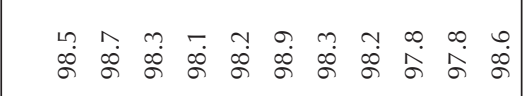 & $\begin{array}{llll}0 & 0 & + & 1 \\
\infty & \infty & 0 \\
\infty & \infty & \infty & \infty \\
\infty & \infty & \infty\end{array}$ & 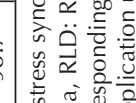 \\
\hline & & 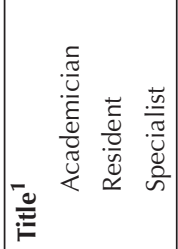 & 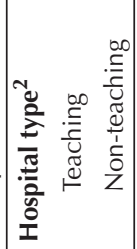 & 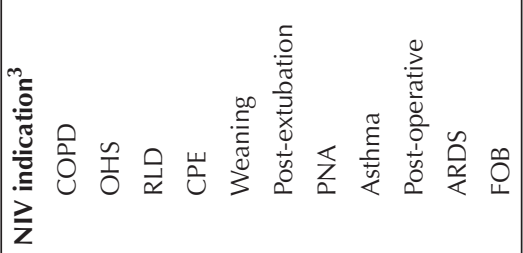 & 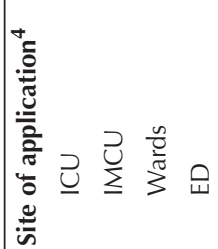 & 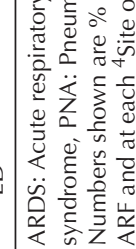 \\
\hline
\end{tabular}


We found some consistency among stated practices independent of the physician's age, title, hospital type or region, especially for indications of COPD and OHS. However, we noted some differences in indications based on one or more of these variables. Younger physicians with higher NIV patient load during residency estimated more frequent NIV use with higher perceived NIV success rates in relatively uncommon indications (such as ARDS, pneumonia, post-extubation, etc.), whereas physicians with a longer duration of NIV experience estimated more frequent use in ACLD. Management of especially hypoxic conditions with NIV had some regional differences as well, which could be due to different numbers and profiles of physicians participating from different regions. So, there are many confounding factors, however, we can at least claim that the approach for ACLD mostly does not change throughout Turkey.

In this study, the application of NIV was shown to be generally not limited to ICU. The majority of the responders $(90 \%)$ reported applying NIV in general wards, which is quite higher than reported by previous surveys $(11-65 \%)(13,16,17,19)$. This could be in accordance with the literature supporting NIV use outside-of-ICU or due to the lower socioeconomic status of Turkey compared to the U.S. or Canada (13,31-33). Additionally, physician's title, hospital type and region were found to be associated with the site of NIV application, such as higher rates of application in non-ICU units in teaching hospitals compared to non-teaching ones. On the contrary, EDs were less preferred by the physicians compared to prior surveys $(13,16)$. We can increase the awareness, availability and frequency of NIV use in EDs by providing equipment and training courses emphasizing the importance of not delaying NIV for transfer of sicker patients, with the possibility of increased mortality otherwise (33-35). Although very infrequent, the restriction of NIV use for IMCU and/or ICU was more prominent for specialists from non-teaching hospitals. Provision of trained staff, technical equipment and in-service training can further decrease this rate.

Perceived success rates for different causal diagnoses of ARF were reported between $60-80 \%$ by generally half of the responders using NIV for that condition, except for lower success rates by a higher proportion of responders for pneumonia and ARDS. Not surprisingly, for most of the diagnoses, these rates were found to be associated with the physician's title and the hospital type (generally improving with higher specialization in the pulmonary field). There is no other survey study providing estimated success rates per diagnosis. In the study of Bierer et al., most of the responders rated it as $26-50 \%$, and less than $10 \%$ felt it was greater than $75 \%$ of the time (17). Three-quarters of the responders in Cabrini et al.'s study also thought that NIV was successful only in less than half of the patients (13). The authors claimed that these low rates could be due to inappropriate use of NIV or could be a misperception. Our success rates were consistent with the actual success rates, shown as $73.9 \%$ in general, $75.8 \%$ for ACLD, $79.4 \%$ for CPE and $45.9 \%$ for de novo ARF (8).

The most commonly preferred mask type for NIV was oronasal, similar to the surveys from Europe and the U.S. and consistent with literature stating that an oronasal mask is more effective or better tolerated by patients in ARF $(12,15,36,37)$. Helmets were perceived to be used very rarely in Turkey, in contrast to Europe, especially Italy (13). Physician's academic degree, hospital type or cause of ARF were found to be associated with preferred mask type, such as a more frequent preference of TFM or helmet masks mostly by the academicians, teaching hospitals or pulmonologists using NIV in hypoxemic ARF. This variation is probably due to increased experience in NIV use by these particular physicians or specialized hospitals.

"Home care" ventilators were the most commonly preferred ventilators. "Bilevel" ventilators were similarly the choice of ventilator in the U.S. and Europe surveys; however, the rate of hospital-type dedicated NIV ventilators was higher than our rates $(12,15,17)$. This could be due to the unavailability of these specialized NIV ventilators in most of the hospitals in Turkey because of their higher cost. Preference for ICU ventilators or hospital-type NIV ventilators by physicians utilizing NIV for hypoxemic conditions can be because of the necessity of the provision of a higher fraction of inspired oxygen by oxygen blenders in these ones, whereas home care ventilators were most often preferred by physicians using NIV for ACLD, like shown in the Europe survey (12). Humidification can protect the airways from dryness, therefore it might increase the tolerance of the patient; however, it was stated to be used by only half of our physicians, as also shown by Crimi et al. $(4,12)$. 
Several limitations of this survey deserve mentioning, the most important of which is our response rate of $27 \%$. Questionnaires were sent by e-mail, however, it is not certain how many of the physicians received the e-mail. A selection bias, favoring physicians who use NIV to respond, might have occurred. Therefore, it is difficult to extrapolate the results of this survey to the whole country; however, similar surveys done in the U.S. and India reported comparable results, at even lower response rates $(17,18,38)$. For logistical reasons, we surveyed only pulmonary physicians, but other branches, such as anesthesiologists or cardiologists, may also use NIV for ARF. All data was self-reported, and no attempts were made to verify them. Since stated practice may differ from actual practice, our results may under or overestimate actual practice variation. The survey instrument did not undergo formalized reliability testing, and some of the questions relied on opinion and recall.

Despite these limitations, we think that the survey provides the first extensive view of NIV practices of Turkish pulmonologists in patients with ARF, and our results are generally consistent with other surveys $(12,15,17,18)$. The variation in NIV practice can be multi-factorial, including physician (such as experience, knowledge or opportunities for these technologies), center (such as teaching status, region of the hospital, availability for a facility/staff/equipment to provide NIV) and patient-related factors (such as the cause or type of ARF). These differences might be decreased by increasing clinical experience, the provision of training to caretakers involved in NIV use and improving conditions of facilities for NIV use $(39,40)$.

\section{CONCLUSION}

The findings of this survey characterize the current approach of pulmonologists in Turkey to NIV use in ARF. Our survey suggests that, despite widespread evidence about the utilization of NIV in ARF in selected patients, nearly $30 \%$ of our pulmonologists still do not use NIV in clinical practice. A lack of equipment, facilities, trained medical staff or experience in NIV might lead to these, which can be improved by support of medical policies favoring NIV use. For NIV users, the major indications, sites and technical equipment were similar within the survey population and consistent with the guidelines and prior surveys. However, there was a variation in practices for specific issues, which can be decreased by in-service training programs across Turkey.

\section{ACKNOWLEDGEMENTS}

The authors would like to thank all pulmonologists participating to the survey.

\section{REFERENCES}

1. Non-invasive ventilation in acute respiratory failure. Thorax 2002; 57:192-211.

2. International Consensus Conferences in Intensive Care Medicine: noninvasive positive pressure ventilation in acute Respiratory failure. Am J Respir Crit Care Med 2001; 163:283-91.

3. Boldrini R, Fasano L, Nava S. Noninvasive mechanical ventilation. Curr Opin Crit Care 2012;18:48-53.

4. Hess DR. Noninvasive ventilation for acute respiratory failure. Respir Care 2013;58:950-72.

5. Keenan SP, Sinuff T, Burns KE, Muscedere J, Kutsogiannis J, Mehta S, et al. Clinical practice guidelines for the use of noninvasive positive-pressure ventilation and noninvasive continuous positive airway pressure in the acute care setting. C maj 2011;183:195-214.

6. Walkey AJ, Wiener RS. Use of noninvasive ventilation in patients with acute respiratory failure, 2000-2009: a population-based study. Ann Am Thorac Soc 2013;10:10-7.

7. Schnell D, Timsit JF, Darmon M, Vesin A, GoldgranToledano D, Dumenil AS, et al. Noninvasive mechanical ventilation in acute respiratory failure: trends in use and outcomes. Intensive Care Med 2014;40:582-91.

8. Ozsancak Ugurlu A, Sidhom SS, Khodabandeh A, leong $M$, Mohr C, Lin DY, et al. Use and outcomes of noninvasive positive pressure ventilation in acute care hospitals in Massachusetts. Chest 2014;145:964-71.

9. Chandra D, Stamm JA, Taylor B, Ramos RM, Satterwhite L, Krishnan JA, et al. Outcomes of noninvasive ventilation for acute exacerbations of chronic obstructive pulmonary disease in the United States, 1998-2008. Am I Respir Crit Care Med 2011;185:152-9.

10. Ozyilmaz E, Ugurlu AO, Nava S. Timing of noninvasive ventilation failure: causes, risk factors, and potential remedies. BMC Pulm Med 2014;14:19.

11. Nava $S$, Ceriana P. Causes of failure of noninvasive mechanical ventilation. Respir Care 2004;49:295-303.

12. Crimi C, Noto A, Princi P, Esquinas A, Nava S. A European survey of noninvasive ventilation practices. Eur Respir I $2010 ; 36: 362-9$

13. Cabrini L, Antonelli M, Savoia G, Landriscina M. Noninvasive ventilation outside of the Intensive Care Unit: an Italian survey. Minerva Anestesiol 2011;77:313-22.

14. Browning J, Atwood B, Gray A. Use of non-invasive ventilation in UK emergency departments. Emerg Med J 2006;23:920-1.

15. Hess DR, Pang JM, Camargo CA Jr. A survey of the use of noninvasive ventilation in academic emergency departments in the United States. Respir Care 2009;54:1306-12. 
16. Burns KE, Sinuff T, Adhikari NK, Meade MO, Heels-Ansdell $D$, Martin CM, Cook DJ. Bilevel noninvasive positive pressure ventilation for acute respiratory failure: survey of Ontario practice. Crit Care Med 2005;33:1477-83.

17. Bierer GB, Soo Hoo GW. Noninvasive ventilation for acute respiratory failure: a national survey of Veterans Affairs hospitals. Respir Care 2009;54:1313-20.

18. Chawla R, Sidhu US, Kumar V, Nagarkar S, Brochard L. Noninvasive ventilation: a survey of practice patterns of its use in India. Indian I Crit Care Med 2008;12:163-9.

19. Maheshwari V, Paioli D, Rothaar R, Hill NS. Utilization of noninvasive ventilation in acute care hospitals: a regional survey. Chest 2006;129:1226-33.

20. Celikel T, Sungur M, Ceyhan B, Karakurt S. Comparison of noninvasive positive pressure ventilation with standard medical therapy in hypercapnic acute respiratory failure. Chest 1998;114:1636-42.

21. Dikensoy O, Ikidag B, Filiz A, Bayram N. Comparison of non-invasive ventilation and standard medical therapy in acute hypercapnic respiratory failure: a randomised controlled study at a tertiary health centre in SE Turkey. Int J Clin Pract 2002;56:85-8.

22. Ciledag A, Kaya A, Akdogan BB, Kabalak PA, Onen ZP, Sen $E$, et al. Early use of noninvasive mechanical ventilation in patients with acute hypercapnic respiratory failure in a respiratory ward: a prospective study. Arch Bronconeumol 2010;46:538-42.

23. Gursel G, Aydogdu M, Tasyurek S, Gulbas G, Ozkaya S, Nazik $S$, et al. Factors associated with noninvasive ventilation response in the first day of therapy in patients with hypercapnic respiratory failure. Ann Thorac Med 2012;7:927.

24. Gungor G, Tatar D, Salturk C, Cimen P, Karakurt Z, Kirakli $C$, et al. Why do patients with interstitial lung diseases fail in the ICU? a 2-center cohort study. Respir Care 2013; 58:525-31.

25. Ucgun I, Yildirim H, Metintas M, Guntulu AK. The efficacy of non-invasive positive pressure ventilation in ARDS: a controlled cohort study. Tuberk Toraks 2010;58:16-24.

26. McCurdy BR. Noninvasive positive pressure ventilation for acute respiratory failure patients with chronic obstructive pulmonary disease (COPD): an evidence-based analysis. Ont Health Technol Assess Ser 2012;12:1-102.

27. Williams JW, Cox CE, Hargett CW, Gilstrap DL, Castillo CE, Govert JA, et al. Noninvasive positive pressure ventilation (NPPV) for acute respiratory failure (Internet). AHRQ Comparative Effectiveness Reviews: Rockville (MD): Agency for Healthcare Research and Quality (US), 2012: Report No. 12-EHCO89-EF.29.

28. Burns KE, Adhikari NK, Keenan SP, Meade MO. Noninvasive positive pressure ventilation as a weaning strategy for intubated adults with respiratory failure. Cochrane Database Syst Rev 2010:CD004127.
29. Vital FM, Ladeira MT, Atallah AN. Non-invasive positive pressure ventilation (CPAP or bilevel NPPV) for cardiogenic pulmonary edema. Cochrane Database Syst Rev 2013;5:CD005351.

30. Carrillo A, Ferrer M, Gonzalez-Diaz G, Lopez-Martinez A, Llamas $N$, Alcazar $M$, et al. Noninvasive ventilation in acute hypercapnic respiratory failure caused by obesity hypoventilation syndrome and chronic obstructive pulmonary disease. Am J Respir Crit Care Med 2012;186:1279-85.

31. Farha S, Ghamra ZW, Hoisington ER, Butler RS, Stoller JK. Use of noninvasive positive-pressure ventilation on the regular hospital ward: experience and correlates of success. Respir Care 2006;51:1237-43.

32. Plant PK, Owen IL, Elliott MW. Early use of non-invasive ventilation for acute exacerbations of chronic obstructive pulmonary disease on general respiratory wards: a multicentre randomised controlled trial. Lancet 2000;355:1931-5.

33. Tomii K, Seo R, Tachikawa R, Harada Y, Murase K, Kaji R, et al. Impact of noninvasive ventilation (NIV) trial for various types of acute respiratory failure in the emergency department; decreased mortality and use of the ICU. Respir Med 2009; 103:67-73.

34. Conti G, Antonelli M, Navalesi P, Rocco M, Bufi M, Spadetta $G$, et al. Noninvasive vs. conventional mechanical ventilation in patients with chronic obstructive pulmonary disease after failure of medical treatment in the ward: a randomized trial. Intensive Care Med 2002;28:1701-7.

35. Roberts CM, Stone RA, Buckingham RJ, Pursey NA, Lowe D. Acidosis, non-invasive ventilation and mortality in hospitalised COPD exacerbations. Thorax 2010;66:43-8.

36. Girault C, Briel A, Benichou J, Hellot MF, Dachraoui F, Tamion $F$, et al. Interface strategy during noninvasive positive pressure ventilation for hypercapnic acute respiratory failure. Crit Care Med 2009;37:124-31.

37. Kwok H, McCormack J, Cece R, Houtchens J, Hill NS. Controlled trial of oronasal versus nasal mask ventilation in the treatment of acute respiratory failure. Crit Care Med 2003:31:468-73.

38. Devlin JW, Nava S, Fong JJ, Bahhady I, Hill NS. Survey of sedation practices during noninvasive positive-pressure ventilation to treat acute respiratory failure. Crit Care Med 2007;35:2298-302.

39. Girou E, Brun-Buisson C, Taille S, Lemaire F, Brochard L. Secular trends in nosocomial infections and mortality associated with noninvasive ventilation in patients with exacerbation of COPD and pulmonary edema. JAMA 2003;290:2985-91.

40. Carlucci A, Delmastro $M$, Rubini F, Fracchia C, Nava S. Changes in the practice of non-invasive ventilation in treating COPD patients over 8 years. Intensive Care Med 2003;29:419-25. 
Copyright of Tuberculosis \& Thorax / Tuberkoloz ve Toraks is the property of Turkish Association of Tuberculosis \& Thorax and its content may not be copied or emailed to multiple sites or posted to a listserv without the copyright holder's express written permission. However, users may print, download, or email articles for individual use. 